\title{
Adult-onset cerebral X-linked adrenoleukodystrophy presenting as obsessive-compulsive disorder
}

\section{Adrenoleucodistrofia ligada ao X forma cerebral do adulto manifestando como transtorno obsessivo-compulsivo}

Wladimir Bocca Vieira de Rezende PINTO', Mário Teruo YANAGIURA', Bruno de Mattos Lombardi BADIA', Luiz Henrique Libardi SILVA', Igor Braga FARIAS', Paulo Victor Sgobbi de SOUZA', Acary Souza Bulle OLIVEIRA'

A 35-year-old man presented with a five-year history of obsessive-compulsive disorder with excessive hand washing (Figure 1). Maternal family history disclosed a threegenerational antecedent of childhood and adult-onset X-linked adrenoleukodystrophy (X-ALD). Examination showed global brisk tendon reflexes and bilateral Babinski sign. Neuroimaging studies showed periventricular white matter lesions (Figure 2). Plasma very-long chain fatty acid concentrations were suggestive of X-ALD. Genetic analysis revealed a definite pathogenic variant $(\mathrm{c} .311 \mathrm{G}>\mathrm{A}$; p.Arg104His) in the $A B C D 1$ gene, confirming the diagnosis of adult-onset cerebral X-ALD.

Personality changes, psychotic symptoms and obsessive-compulsive disorder may be the presenting features of adult-onset cerebral X-ALD ${ }^{1,2,3}$, preceding the onset of motor compromise $\mathrm{e}^{1,2,4}$.
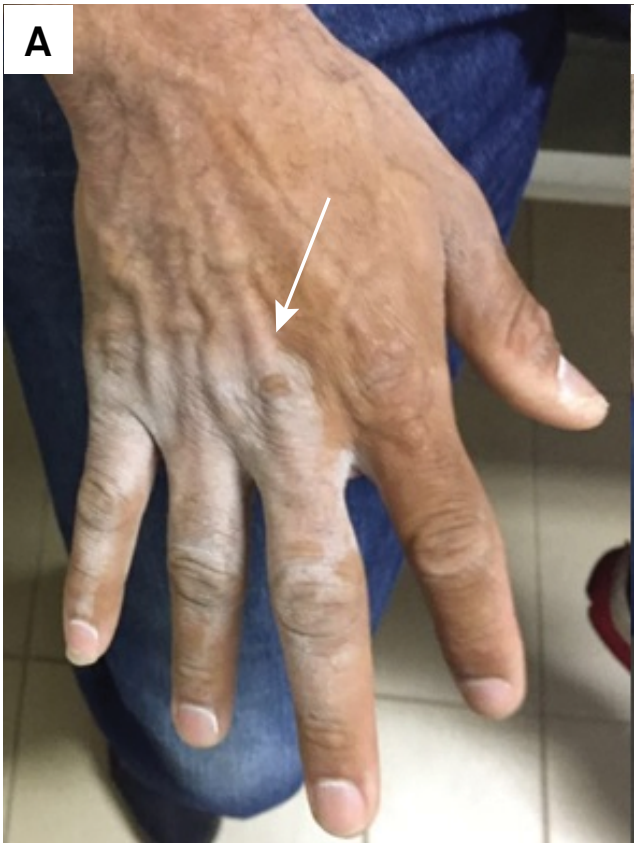

B

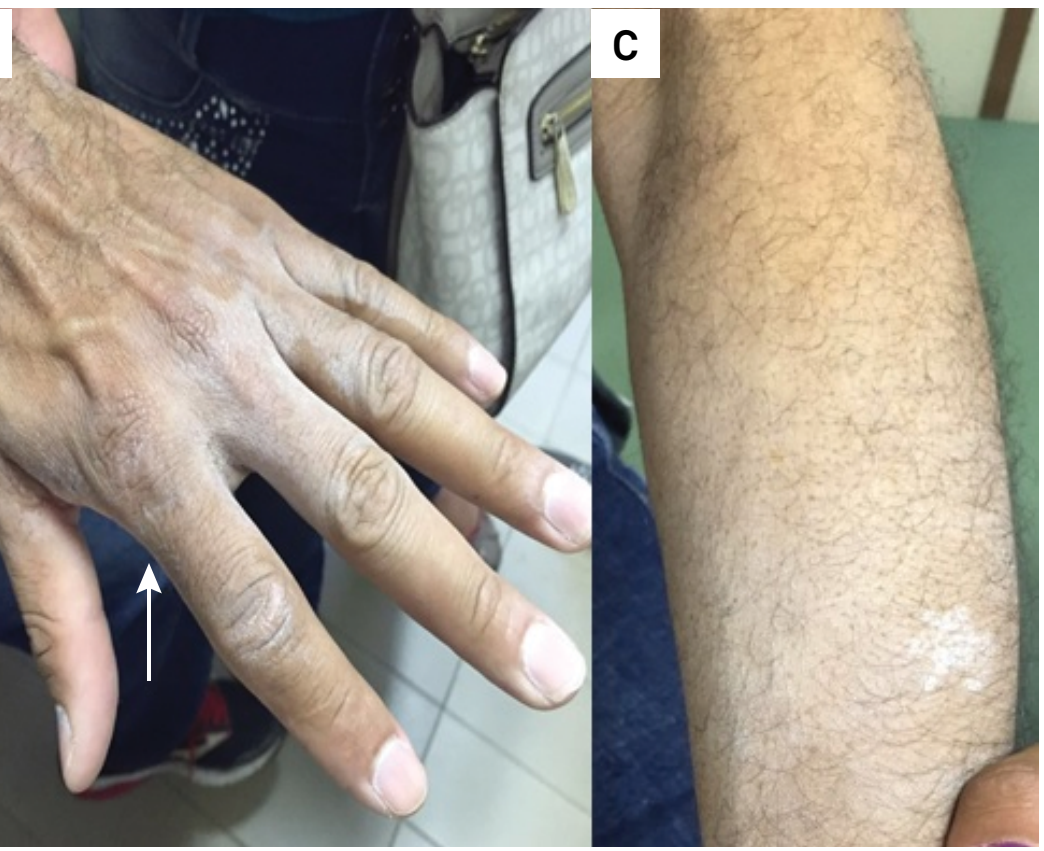

Figure 1. Examination findings in obsessive-compulsive behavior in adult-onset cerebral X-linked adrenoleukodystrophy. (A-C) Ectoscopic evaluation revealed the presence of excoriations and superficial traumatic exfoliations of the epidermis in the extensor surface of hands and forearms (white arrows).

'Universidade Federal de São Paulo, Departamento de Neurologia e Neurocirurgia, São Paulo SP, Brasil.

Wladimir Bocca Vieira de Rezende Pinto (iD) https://orcid.org/0000-0002-0150-525X; Bruno de Mattos Lombardi Badia iD https://orcid.org/0000-0001-7360-0494; Paulo Victor Sgobbi de Souza iD https://orcid.org/0000-0002-7416-7108; Acary Souza Bulle Oliveira iD https://orcid.org/0000-0002-6986-4937 Correspondence: Wladimir Bocca Vieira de Rezende Pinto; Departamento de Neurologia e Neurocirurgia/UNIFESP; Rua Estado de Israel, 899; 04022-002 São Paulo SP, Brasil; E-mail:wladimirbvrpinto@gmail.com

Conflict of interest: There is no conflict of interest to declare.

Received 09 February 2019; Accepted 19 June 2019. 


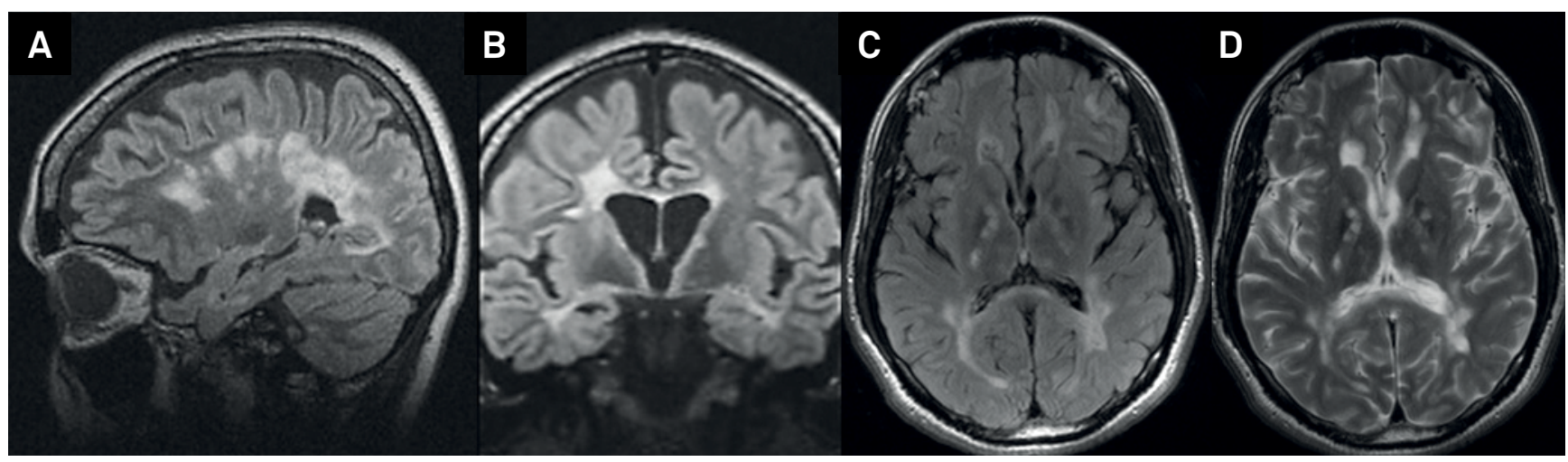

Figure 2. Neuroimaging studies in adult-onset cerebral X-linked adrenoleukodystrophy. (A) Sagittal and (B) coronal brain MR imaging showing confluent asymmetric periventricular hyperintense lesions in FLAIR sequence. Axial brain MR imaging also revealed the involvement of the corpus callosum and internal capsule in FLAIR (C) and T2-weighted images (D).

\section{References}

1. Engelen M, Kemp S, de Visser M, van Geel BM, Wanders RJ, Aubourg P, et al.X-linked adrenoleukodystrophy (X-ALD): clinical presentation and guidelines for diagnosis, follow-up and management. Orphanet $\mathrm{J}$ Rare Dis. 2012 Aug;7(1):51. https://doi.org/10.1186/1750-1172-7-51

2. Sutovský S, Petrovic R, Chandoga J, Turcáni P. Adult onset cerebral form of X-linked adrenoleukodystrophy with dementia of frontal lobe type with new L160P mutation in ABCD1 gene.J Neurol Sci. 2007 Dec;263(1-2):149-53. https://doi.org/10.1016/j.jns.2007.01.082
3. Garside S, Rosebush PI, Levinson AJ, Mazurek MF.

Late-onset adrenoleukodystrophy associated with long-standing psychiatric symptoms. J Clin Psychiatry. 1999 Jul;60(7):460-8. https://doi.org/10.4088/JCP.v60n0708

4. Galvão AC, Machado-Porto GC, Porto FH, Lucato LT, Nitrini R. Adultonset adrenoleukodystrophy presenting as a psychiatric disorder: MRI findings. Dement Neuropsychol. 2012 Oct-Dec;6(4):290-5. https://doi.org/10.1590/S1980-57642012DN06040015 